\section{ALC 下地に対する機械的固定 工法防水層の固定部分の耐疲労 性}

\section{FATIGUE RESISTANCE OF MECHANICALLY FASTENED WATERPROOFING SYSTEMS TO ALC SUBSTRATE BY REPETITIVE LOADINGS}

\author{
バルトコ ミハエルー*1 \\ 田中享二 \\ 宮内博之— $* 2$ \\ キーワード : \\ 試験方法, 防水層機械的固定工法, 疲労試験装置, 耐風性, ALC, 破壊形態
}

Keywords : apparatus, Wind resistance, Autoclaved lightweight concrete, Fracture mode
Test method, Mechanically fastened waterproofing system, Fatigue

\author{
Michal BARTKO -*1 \\ Kyoji TANAKA —* 3 \\ Hiroyuki MIYAUCHI — $* 2$
}

This report deals with the results by the two types of the fatigue tests. First, performed on the nowadays regularly used fastening elements applied to the ALC panel substrates, and the second performed on the complete mechanically fastened waterproofing systms. The improvements of the problematic issues are also considered. Based on the first fatigue test results, we can state that the resistance of the fasteners and the ALC substrate, to the repetitive effect, is decreased. Moreover, depending on the fastening method, there are differences between the fatigue resistances of the fastening elements. The fatigue resistance is improving in the following order: the directly applied screws, the PA plug using fasteners, and the chemical fasteners with in advance injected epoxy resin. Test results of the both fatigue tests were compared. We can state that for the present waterproofing systems, the weak point is not the low strength of the ALC substrate, but the strength of the waterproofing membrane and/or the part of the force transmission from the fastener to the membrane. We presume that there is some potential to improve these problems.

\section{1.はじめに}

固定用アンカー（以降、アンカーと示す。）類を用いて防水層を下 地に留めつける機械的固定工法は、基本的には乾式工法であり、接 着工法に比べて作業環境や下地の影響を受けにくいという特徵を持 っている。特に改修工事では、既存の防水層氏゙押え層を撤去せずに 新たな防水層施工が可能であることから、非常に好まれて使用され るようになっている。

一方、この工法による防水層には、従来にも増して強風時の安全 性確保が求められる。強い風が防水層面を走ると、吸い上げ力が発 生し、図 1 に示すように上方への力が作用する。さらに防水層はフ ラッタリングを起こすため、多数回の繰り返しの疲労を受ける ${ }^{1)}$ 。 この工法では、防水層の下地への固定はアンカー類だけを介してな されるため、下地も含めた固定部分が耐風性の要となる。従来から 鉄筋コンクリート下地では、この工法の信頼性は高く、また構造分 野でも後付けアンカー工法としての実績も多い。しかし ALC 下地に 対しては、その強度がコンクリートに比して低いため、その適用に は慎重な取り扱いがなされる必要がある。実際に JASS8・防水工事 ${ }^{2)}$ においても、ALC 下地一の機械的固定工法の採用は特記によるとさ れ、設計者の責任のもとに使用することとされ、標準仕様として取 り上げられていない。その主たる理由は ALC 下地を対象とした時の 固定部分の研究とデータが不足しているためである。しかし一方で プレファブ住宅等での採用例は多く、その実績も增えてきている。

このように、一方では慎重な構えを崩さず、他方では施工が増え ているといった状況はユーザーに対して混乱を招くばかりでなく、 健全な技術の進歩を遅延化させる。今後は、ALCを下地とした機械的 固定工法のデータを示してゆく必要がある。幸い防水システムの強
風時の繰り返し疲労の影響を調べるための簡便な試験方法も開発さ れている ${ }^{3)}$ 。本報告は、現在一般に利用されているアンカーによる ALC 下地固定部分の繰り返し載荷試験の結果を開示するものである。 さらにこの結果をもとに、現在の防水層も含めた機械的固定工法の システムとしての耐風性について調・、、その問題点と今後の改善点 を考察したものである。

既往の研究についてであるが、そのほとんどは試験体の上に吸引 箱をかぶせ、内部を風外力に相当する負圧とし、破壊が起きるかど うかを評価する方法がとられていた ${ }^{2)}$ 。この方法は、防水システム 全体の耐風性を数百回程度の限られた回数で評価するには有効な試 験方法であるが、実際の風を想定した多数回の繰り返し疲労に対し ての、防水層固定部分の耐疲労性の検討には限度があった。また、 Baskaran 等 ${ }^{4-6)}$ は各種防水層における耐風性の試験方法を提案して いるが、防水システムにおける下地、アンカー、防水層の個々の耐 疲労性については検討がなされていない。今後は、防水層機械的固 定工法の耐風性を評価する上で、固定部への多数回の繰り返し載荷 に対する耐疲労性を調べておく必要があると考えられる。

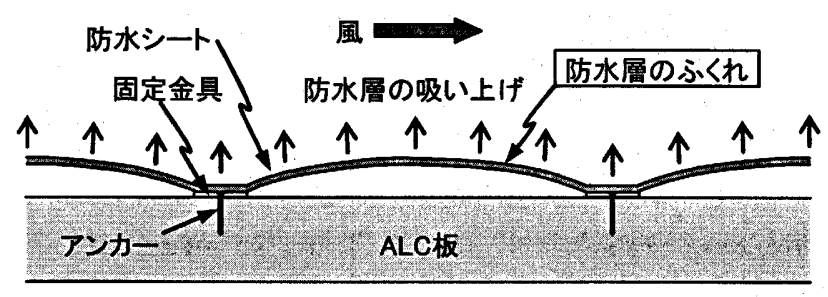

図1 風の吸い上げカによる防水層のふくれ状態

\footnotetext{
*1 東京大学生産技術研究所 研究員 · 博士 (工学)

(元 東京工業大学 大学院生, 干226-8503 横浜市緑区長津田町4259)

*2 束京工業大学建築物理研究センター 助手・博士 (工学)

*3 東京工業大学建築物理研究センター 教授・ 工博
} 


\section{2. アンカーによるALC 下地への固定部分の静的引き抜き試験}

\section{1 試験体}

現在さまざまなアンカーが使用されているが、基本的には下地に ねじ状アンカーを直接ねじ込むタイプと、事前に ALC 下地に下穴を 開けておき、プラスチック製プラグを打ち込み、それにアンカーを ねじ込むタイプ、さらにプラグ打ち込みに際して接着性を高めるた めにエポキシ樹脂接着剤を併用し、それにアンカーをねじ込むタイ プの 3 種類が、実務で多く用いられる。そのためここではその 3 種 類を試験体とした。

表1 ALC下地への固定
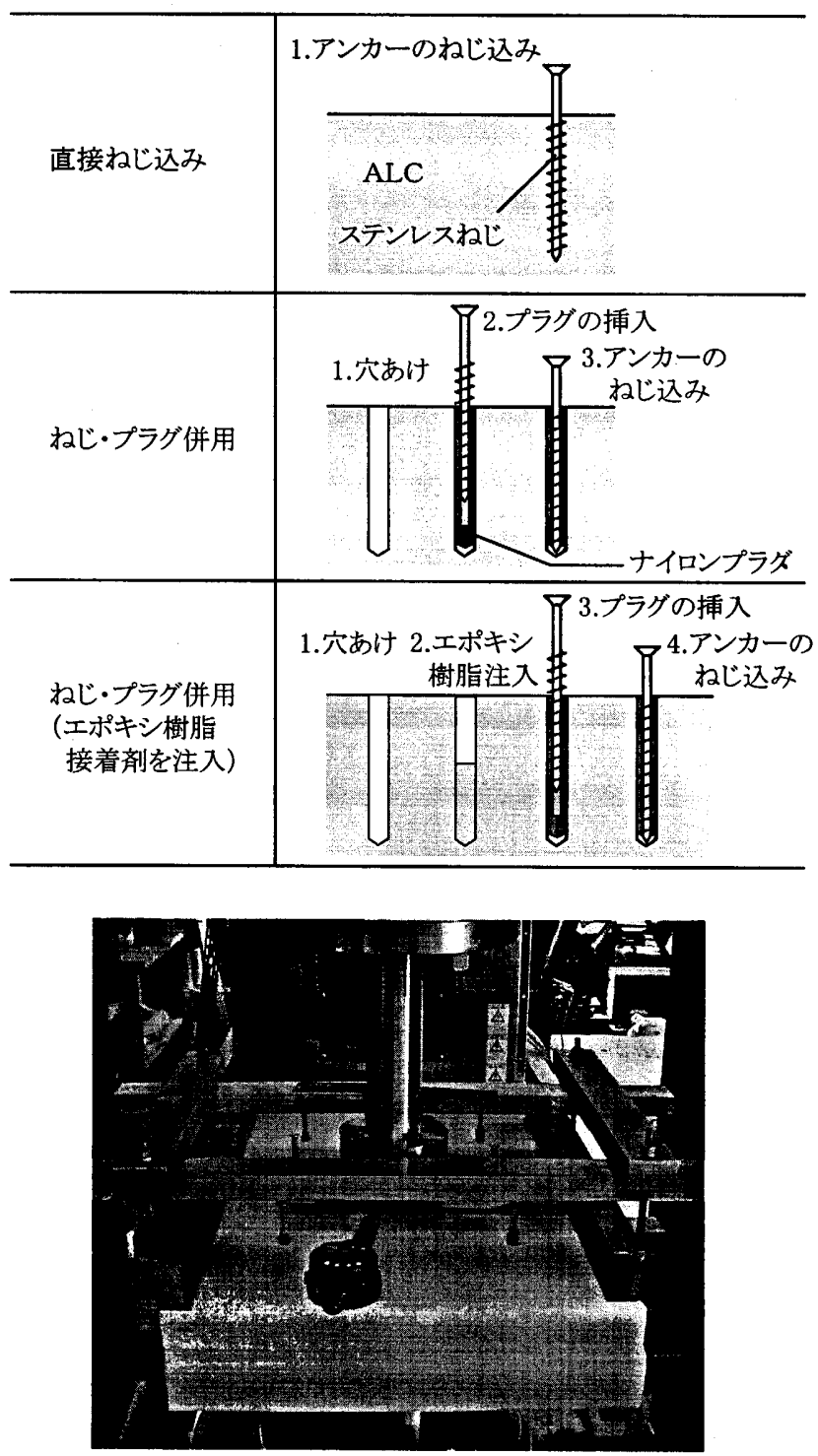

写真1 引抜き試験の状況

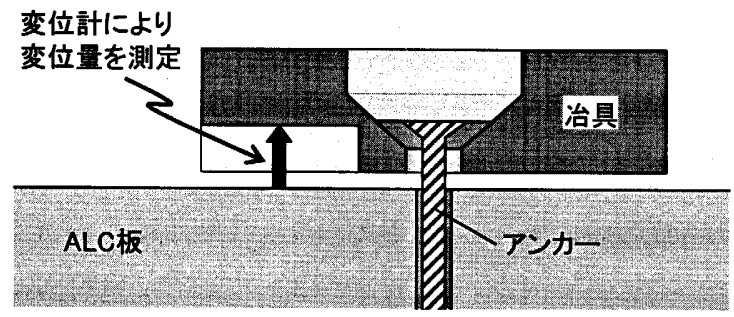

図2 引抜き荷重測定の構成
その際、埋め込み深さが重要となるが、ここでは各固定法とも標 準的に指定されている深さ $65 \mathrm{~mm}$ とした。なお、プラグを併用する タイプについては、下穴径及びプラグ径とも $8 \mathrm{~mm}$ とした。表 1 に固 定法の種類と、固定のための手順を示す。なお試験体数はそれぞれ 3 体ずつとした。試験に用いた ALC は、補強鉄筋入りの屋根用パネ ルであり、厚さ $100 \mathrm{~mm}$ とした。また、現在 JIS A 5416-1997 軽量気 泡コンクリートパネル (ALC パネル) ではその最低強度が $3.0 \mathrm{~N} / \mathrm{mm}^{2}$ と定められており、それに準じて製品が作られているため、パネル は特に変数とはしなかった。

\section{2 引抜き試験の概要}

測定にはインストロンタイプの引張り試験機（最大荷重 : $500 \mathrm{kN}$ ） を用いた。試験の状況を写真 1 に示す。測定にはアンカーを偏心さ せることなく垂直に引き抜くため、図 2 に示す治具を作製し使用し た。またこの治具と ALC 下地との間に変位計を取り付け、アンカー の抜けの変位量を測定した。引張り速度は $1 \mathrm{~mm} /$ 分とし、測定は温度 $20 \pm 2^{\circ} \mathrm{C}$ 環境下で行った。

\section{3 試験結果}

図 3 に荷重一変位曲線の試験結果を示す。いずれもアンカーが引 き抜かれるに従い、荷重は上昇するが、最大値に到達した後、直接 ねじ込みの場合はねじの谷部分に ALC 部分を挟みこみながら、また ねじ・プラグ併用の場合はプラグ部分が ALC 下地から抜けながら、 荷重を徐々に低下させた。樹脂注入試験体ではプラグは抜けなかっ たが、最大荷重時に ALC 部分をコーン状に大きく破壊させ、荷重が 急激に低下した。

平均破壞強度について、アンカーの直接称じ込みの場合は $1.6 \mathrm{kN} 、$

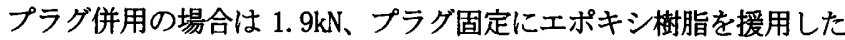
場合は $4.6 \mathrm{kN}$ であった。

3. アンカーのALC 下地への固定部分の絽り返し载荷に対する抵抗性 3.1 試験体

試験体は前節の静的引拔き試験に用いたものと同様である。

\section{2 繰り返し載荷試験の概要}

（1）試験条件

繰り返し載荷試験には、油圧サーボ式疲労試験装置を使用した。 周期は風洞実験による防水層のフラッタリングの測定結果 ${ }^{1}{ }^{1}$ を参考 に $10 \mathrm{~Hz}$ とした。また繰り返し回数は、最大 $10{ }^{7}$ 回までとした。こ

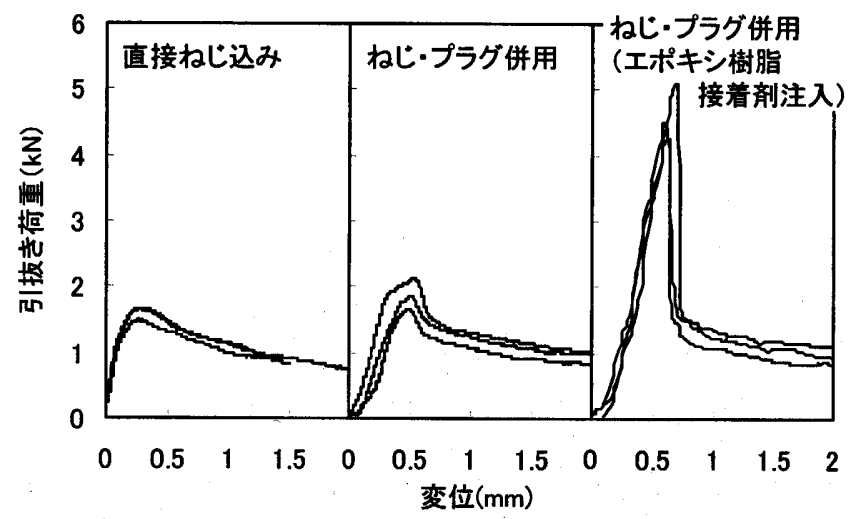

図3 アンカーの荷重-変位曲線 
れは強い台風が年 2 回、それが $10 \mathrm{~Hz}$ のばたつきで 12 時間継続した 場合を想定すると、10 年間でほぼこの程度の繰り返し回数となる。 なお試験はすべて温度 $20 \pm 2{ }^{\circ} \mathrm{C} て ゙$ 行った。

（2）繰り返し荷重

繰り返し荷重ついては、片振幅による引張載荷とした。しかし、 ここで使用した試験機の低荷重時の制御能力が充分ではなく、厳密 に目標荷重值に設定できない場合もあり、また本研究では引抜き荷 重と破壊までの繰り返し回数との関係を求めることを重視してい るため、下記の考え方により試験条件を設定した。すなわち、1回
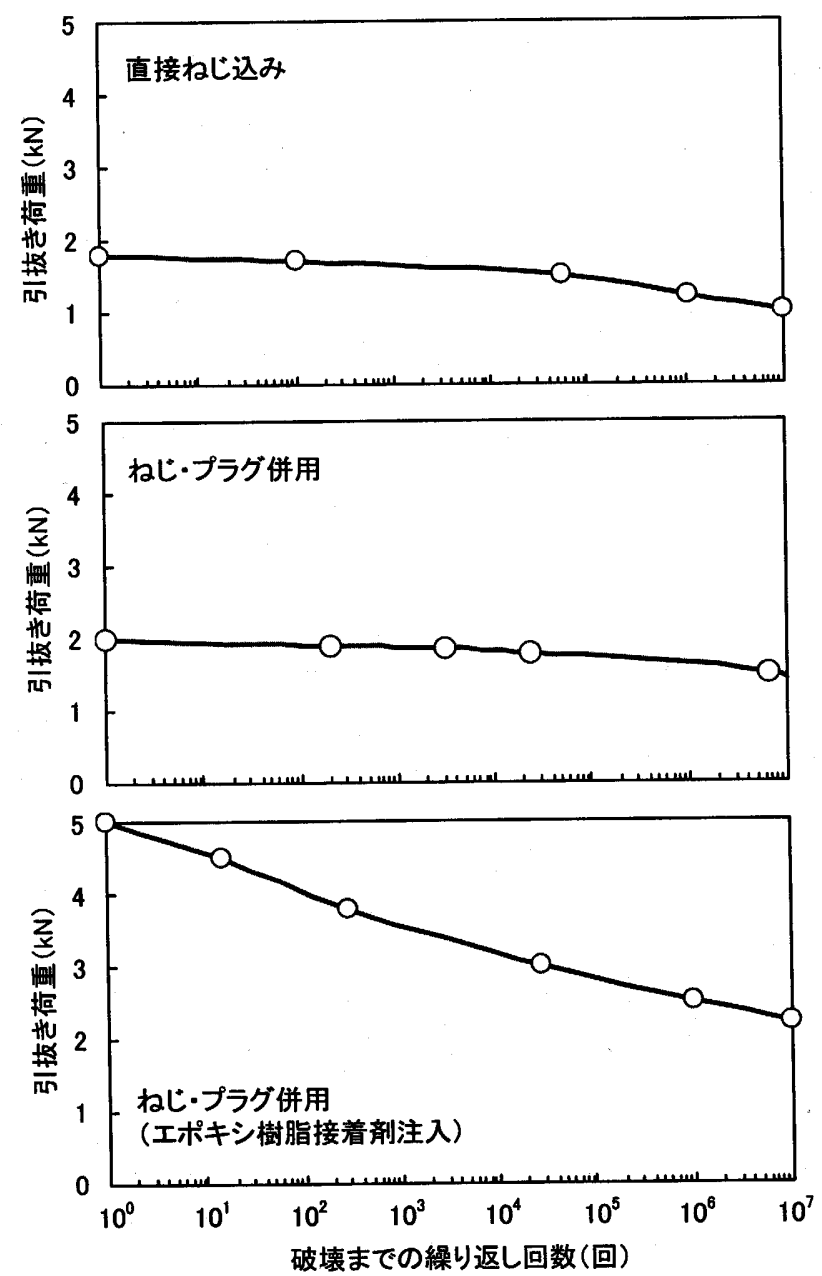

図4 繰り返し疲労試験結果

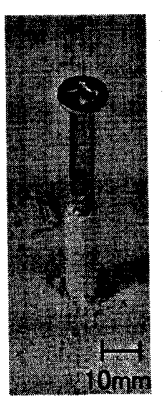

直接ねじ込み ねじ·プラグ
併用

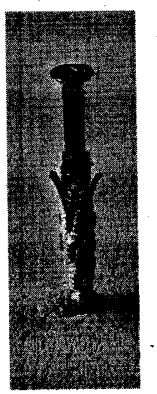

ねじ・プラグ併用

（エポキシ樹脂接着羭注入）

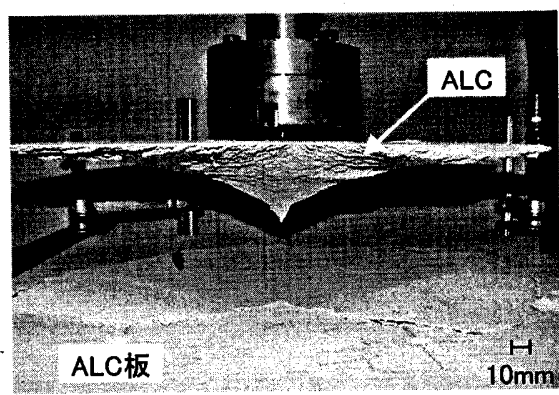

写真2 破壊モード
で抜けてしまう最大の荷重值を基準とし、それに対する比をおおよ そ1割ずつ減少させ、破壊までの荷重を調べることとした。また繰 り返し回数については、一般に疲労試験では $10^{6} \sim 10^{7}$ 回が限度と して評価されることが多いため、ここでは $10^{7}$ 回程度で打ち切った。 実験に際しては、実際に負荷されている荷重をモニターしながら試 験を行った。

\section{3 試験結果}

試験結果を図 4 に示す。すべての試験体について、負荷荷重低下 に伴い、破損発生までの繰り返し回数は増加する傾向が見られる。 繰り返し回数 $10^{7}$ 回での破損の想定される荷重は、直接ねじ込みタ イプでは約 $1 \mathrm{kN}$ 、プラグ併用タイプでは約 $1.5 \mathrm{kN}$ 、さらにそれにエ ポキシ樹脂接着剤を使用した場合では約 $2.2 \mathrm{kN}$ であった。プラグ打 ち込み時にエポキシ樹脂を使用する固定法の繰り返し載荷に対す る抵抗性が最も高かった。また $10^{7}$ 回繰返し後の静的荷重に対する 荷重保持率は、各々、0.56、0.75、0.44であり、全体的にかなり低 下する。

破壊モードは写真 2 に示すように、直接ねじ込みタイプでは、ね じの谷部に ALC 材料をかみ込みながら、プラグ併用タイプではプラ グ部分が引き抜けるような状態で破壊した。一方、プラグの打ち込 みの際にエポキシ接着剤を使用した場合はアンカー近傍での破壊 は全く生じず、コーン状にALC 部分を大きく破壊させた。

\section{4. 風の吸い上げを模擬した防水層の繰り返し載荷試験 4. 1 試験体}

防水層機械的固定システムでは写真 3 に例を示すような、防水シ ート、シートとアンカーを接合させるための円板状固定金具 (以降、 固定金具と示す。）、そして固定金具を下地に固定するためのアンカ 一の 3 要素から構成される。そして実務ではそれらが種々組み合わ せられてシステムを構成している。そのため、ここでは ALC 下地を 対象として現在実務で使われている防水層機械的固定システムを 整理し、表 2 に示す 6 種類の試験体を用意した。

基本的には、図 5 に示すように、まず防水シートと接合させる固 定金具をアンカーでALC 板に固定し、その後、防水シートを固定金 具に接着し、防水システムを完成させる（先付け工法）か、逆に防 水シートを先に敷設し、固定金具をかぶせた後、アンカーでALC 下 地に固定する（後付け工法）かの 2 種類に大別される。前者の構成 ではシートに孔を開けることなく防水システムを作り上げること ができるという利点を持つが、固定金具との接着の良否がこのシス テムの耐風性能に影響を及ぼすことになる。一方、後者の構成では、 固定金具が防水シートの上から直接アンカーにより固定されるた め、接着の問題は回避できるが、防水シートに孔をあけてしまうた め、実際の施工では、その部分のさらなる防水処置が必要となる。 どちらの構成にするかは防水システム製造者の考え方に依存して おり、現行では両方のシステムが使用されている。

次に使用材料であるが、防水シートは下地が ALC の場合に 多く 使用されている塩化ビニル樹脂系シート ${ }^{7}$ とした。基本はガラスク ロス入り複合タイプ塩化ビニル樹脂シートであるが、2004 年 9 月の 防水層の台風被害より、シートの高勒性化が図られポリエステル樹 脂製補強クロス入り複合タイプ塩化ビニル樹脂シートも使われる 
ようになっているため、これも試験体に加えた。これら防水シート の機械的性質を図 6 に示す。

次に固定部分についてであるが、これは防水システムごとに異な り、標準化されていない。システムによっては帯状鋼板を使用する こともある。ただ基本的な考え方はすべて同じであり、その中でも 多くのシステムで採用されている、塩化ビニル樹脂コーティングの された金属製固定金具を用いた。

アンカーについても、種類が非常に多い。この中でやはり使用例 の多い、まずALC 板に下穴を開け、次にプラスチックプラグ（エポ キシ樹脂接着剤注入なし）を埋め込み、最後にネイルを打ち込み防 水層を固定するタイプのものを使用した。これについてはアンカー 長さ $40 \mathrm{~mm} 、 65 \mathrm{~mm}$ の 2 種類とした。なお試験体数は各々 2 体である。 4.2 試験装置

試験装置は筆者等の開発した、写真 4 に示す耐風性評価試験装置 を使用した。これは強風時に防水層に負荷される吸引力を、防水層 の試験体の下側に挿入したエアバッグに空気を供給し、防水層を下 から押し上げ、防水層に強風時と相似の外力を作用させるようにし たものである。これは従来の吸引箱方式の耐風試験装置 ${ }^{2)}$ に比べ、 防水層上面を開放した状態での試験ができるため、試験体の直接観 察が可能という特徴を持っている。

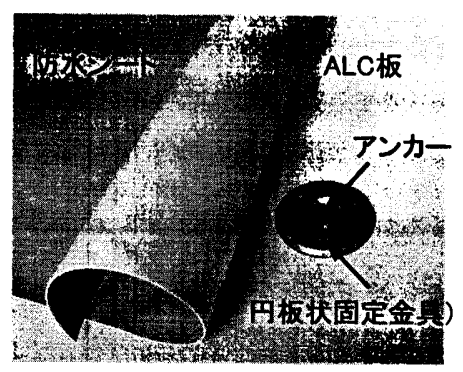

写真3 防水層機械的固定工法の粠成

表2 試験体

\begin{tabular}{|c|c|c|c|}
\hline $\begin{array}{l}\text { 試験体 } \\
\text { 番号 }\end{array}$ & $\begin{array}{c}\text { 固定金具 } \\
\text { 施工 } \\
\end{array}$ & 防水シート & \begin{tabular}{|l} 
アンカーの \\
埋め込み深さ
\end{tabular} \\
\hline No.1 & \multirow{2}{*}{$\begin{array}{l}\text { 先付け } \\
\text { 工法 } \\
\end{array}$} & \multirow{2}{*}{$\begin{array}{l}\text { 複合タイプ塩化ビニルシート(標準用) } \\
\text { :ガラスクロス入り、厚さ } 1.5 \mathrm{~mm}\end{array}$} & \multirow{2}{*}{$\begin{array}{l}40 \mathrm{~mm} \\
65 \mathrm{~mm} \\
\end{array}$} \\
\hline No.2 & & & \\
\hline No. 3 & \multirow{2}{*}{$\begin{array}{l}\text { 後付け } \\
\text { 工法 }\end{array}$} & \multirow{2}{*}{$\begin{array}{l}\text { 複合タイプ塩化ビニルシート(標準用) } \\
\text { :ガラスクロスス、厚さ } 1.5 \mathrm{~mm}\end{array}$} & \multirow{2}{*}{$\begin{array}{l}40 \mathrm{~mm} \\
65 \mathrm{~mm} \\
\end{array}$} \\
\hline No.4 & & & \\
\hline No.5 & \multirow{2}{*}{$\begin{array}{l}\text { 後付け } \\
\text { 工法 }\end{array}$} & \multirow{2}{*}{$\begin{array}{l}\text { 複合タイプ塩化ビニルシート(高強度用) } \\
: \text { ポリエステル樹脂製の補強クロス入り、 } \\
\text { 厚さ } 1.5 \mathrm{~mm}\end{array}$} & \multirow{2}{*}{$\begin{array}{l}40 \mathrm{~mm} \\
65 \mathrm{~mm}\end{array}$} \\
\hline No. 6 & & & \\
\hline
\end{tabular}

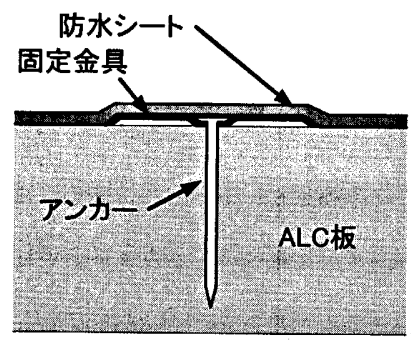

固定金具の先付け工法

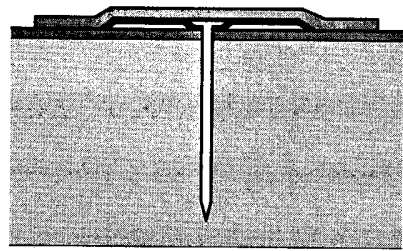

固定金具の後付け工法
図5 円板状固定金具の取付け方法 ${ }^{2)}$

\section{3 試験条件と試験方法}

下地は、前章と同様に厚さ $100 \mathrm{~mm}$ の屋根用 ALC 板であり、これに $1000 \mathrm{~mm} \times 1000 \mathrm{~mm}$ の面積の防水シートを、所定の固定金具を用いて、 下地に固定した。なお固定位置は試験体中央部である。周囲はアン グル状固定板で固定した。

加圧力は、わが国の基本風速の下限值 $30 \mathrm{~m} / \mathrm{s}$ と最大值 $50 \mathrm{~m} / \mathrm{s}$ につ いて、コーナー部で建築物荷重指針より計算される $2.9 \mathrm{kN} / \mathrm{m}^{2}$ と $8.2 \mathrm{kN} / \mathrm{m}^{2}$ の 2 水準を上限とし、下限荷重ゼロ状態との間を繰り返す、

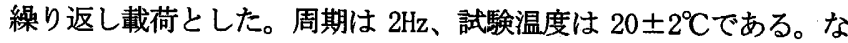
お、本試験でも ALC 下地のみの繰り返し載荷試験の周期 $10 \mathrm{~Hz}$ と同 じ条件で行うことが望ましいが、本試験装置の能力の限界が周期 $2 \mathrm{~Hz}$ であるため、この周期で試験を実施した。また、ALC 下地のみ の繰り返し載荷試験において、あらかじめ $1 \mathrm{~Hz}$ から $10 \mathrm{~Hz}$ までの周 期依存性試験を予備的に実施しており、周期の違いにより破壊まで の繰り返し回数が大きく異ならないことを確認している。

試験の途中で、1000 回ごとに試験機を停止させ、目視により固定 金具および近傍の防水層破壊の有無を観察した。試験は試験体が破 損するまでとした。

\section{4 試験結果}

試験結果の一部はすでに報告している ${ }^{3)}$ が、今回さらに追加して 行なった試験体も含め、それらを一括して図 7 に示す。

おおよそ風速 $30 \mathrm{~m} / \mathrm{s}$ の状況を想定した、荷重 0-2.9kN/ $\mathrm{m}^{2}$ の繰り

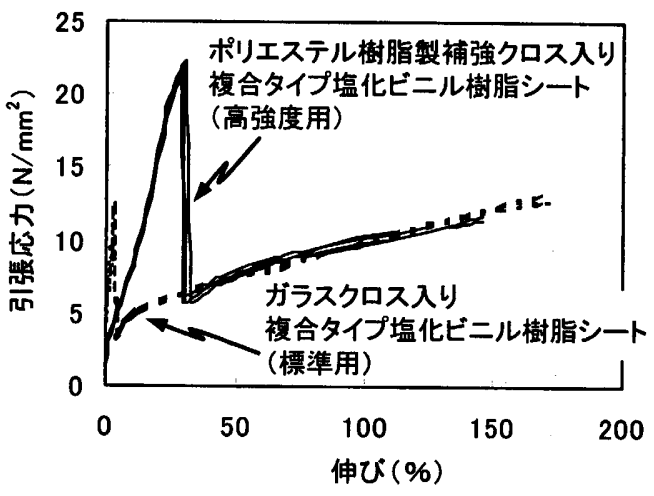

図6 防水シートの応カー伸びの関係

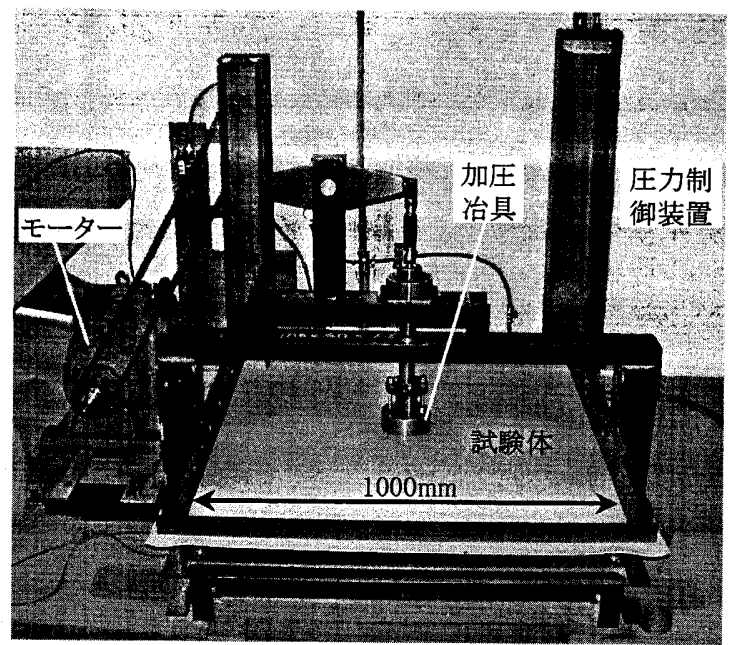

写真4＼cjkstart作製した試験装置 
加圧力 : $0 \mathrm{~N} / \mathrm{m}^{2} \Leftrightarrow 2,9 \mathrm{kN} / \mathrm{m}^{2}$ の場合

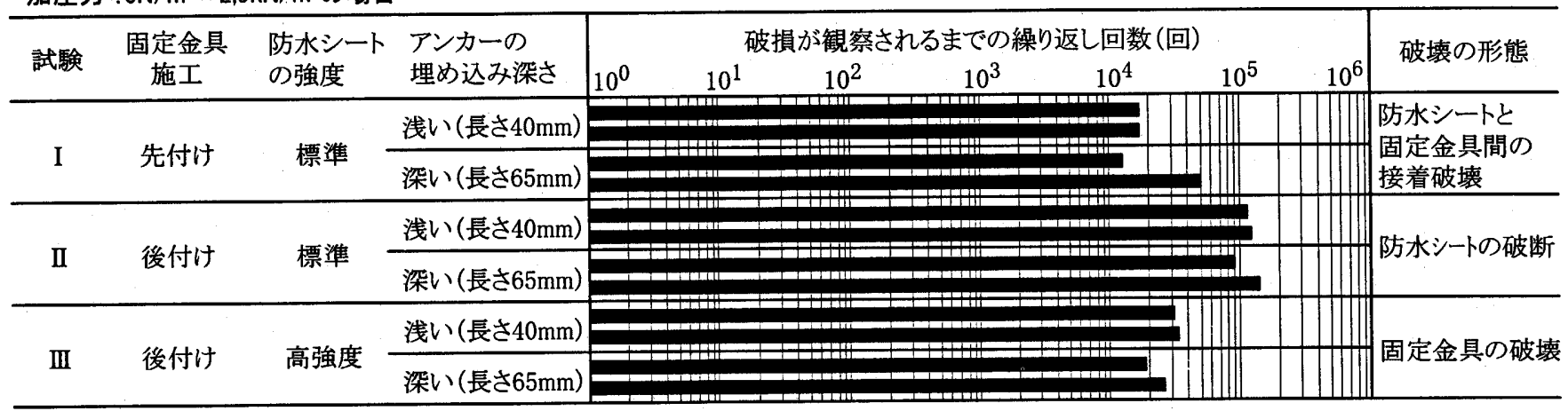

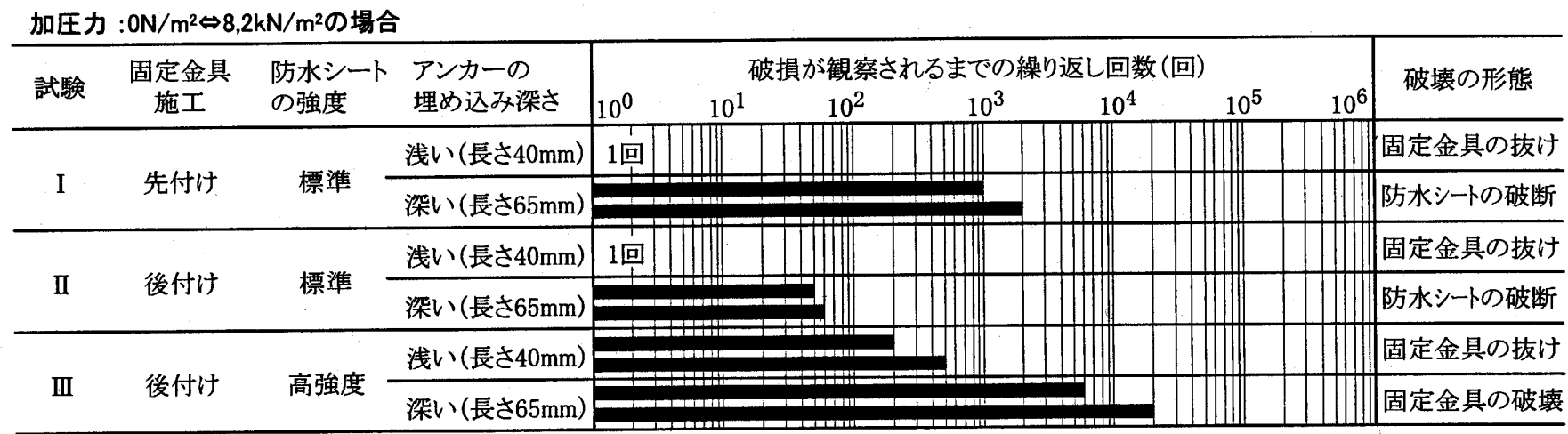

図7 疲労試験結果

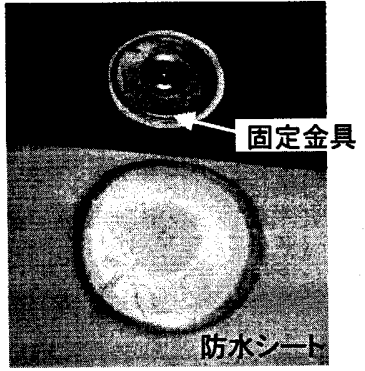

写真5 防水シートと固定金具間の接着破壊

返し載荷の場合には、数万から数十万回で破損した。損傷のすべて は防水シートと固定板に係わるものであった。すなわち固定金具の 先付けの後、防水シートをそれに貼り付ける工法の場合は、写真 5 に見られるような両者の接着部が損傷を受け、剥離が生じた。固定 金具を防水シートの上から固定するシステムの場合は、ガラスクロ ス入り複合タイプ塩化ビニル樹脂シート仕様では、写真 6 に示され るように固定金具のエッジから防水層の破損が始まり、それが拡大 した。強度の高いポリエステル樹脂製補強クロス入り複合タイプ塩 化ビニル樹脂シートでは、防水層からの破損はなくなったが、アン カー周りの固定金具自身の金属疲労により、写真 7 に見られるよう に円形状に破損した。

風速 $50 \mathrm{~m} / \mathrm{s}$ を想定した、荷重 0-8.2 $\mathrm{kN} / \mathrm{m}^{2}$ の繰り返し載荷試験の 場合は、アンカーの打ち込み深さの浅い $40 \mathrm{~mm}$ 場合、 1 回〜数 100 回 の繰り返しで、す心゙て ALC 板からの引き抜けが生じた。しかし実務 で採用されている深さ $65 \mathrm{~mm}$ の場合はアンカーの引き抜けは全くな く、ガラスクロス入り複合タイプ塩化ビニル樹脂シートの場合はシ ートの破損、強度の高いポリエステル樹脂製補強クロス入り複合タ

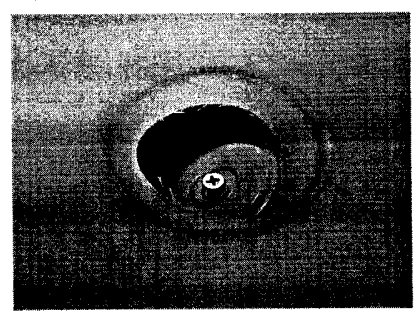

写真6 防水シートの破断
写真7 固定金具の破壊
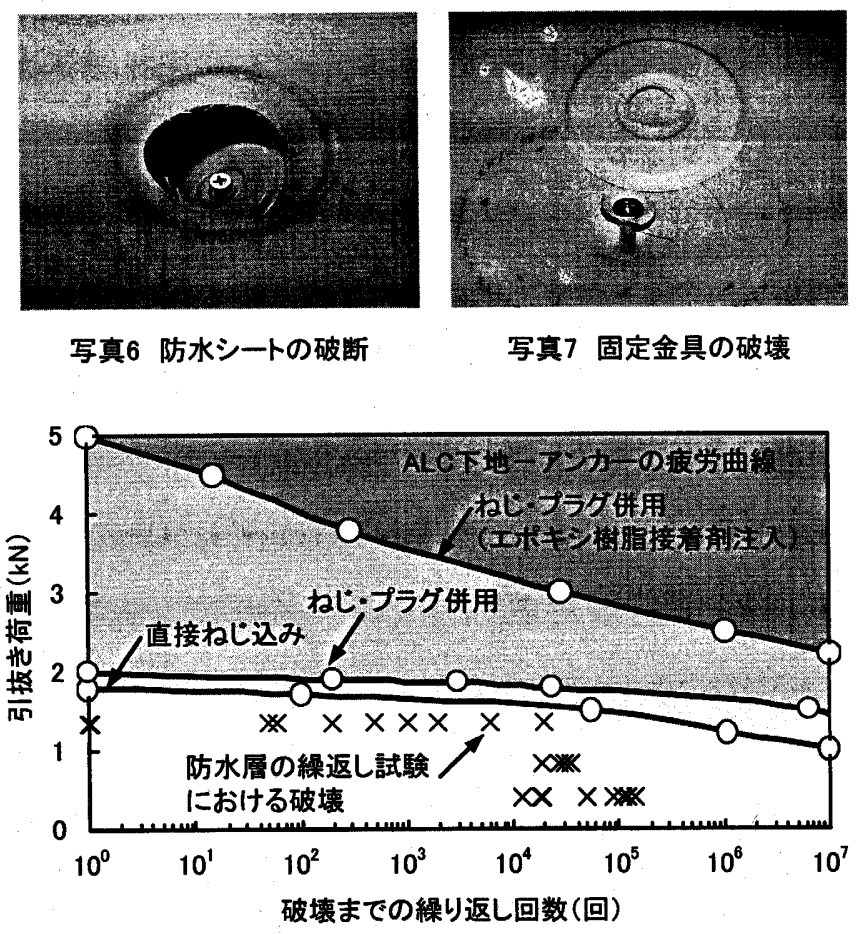

図8 綝り返し疲労試験結果の比較(ねじ·プラグ併用)

イプ塩化ビニル樹脂シートの場合は固定金具自身の金属疲労によ り破損した。

\section{5. 考察}

前章で用いた図 4 の 3 種類のアンカーによる固定法（埋め込み深 さ65mm) の疲労曲線に、図 7 の防水層機械的固定工法のすべての繰 
り返し載荷試験の結果を書き加えた結果を図 8 に示す。これをみる と防水層繰返し試験では種々の損傷が見られたが、すべて ALC 下地 ーアンカー試験における疲労曲線より下側、すなわち疲労曲線より 低い荷重と繰り返し回数の領域に存在している。

このことは、現状ではALC 強度が低いため当初彩念された ALC 下 地からの引き抜け、あるいはALC 板の疲労破壊に問題があるという よりは、防水シート、もしくはシートからアンカーまで力を伝達さ せる部分に問題のあることを示すものである。また 2004 年秋の台 風による防水層の被害 ${ }^{8)}$ でも、損傷の多くは防水シート、またはシ 一トからアンカーまでのカの伝達機構で発生しており、この事を裏 付けていると考えられる。現状ではその部分の改善が急務であると 思われる。

\section{6. 結論}

現在 ALC 下地に多く使用される、アンカーを用いた防水層機械的 固定工法の繰り返し載荷の影響を検討した。本研究の結論は次の通 りである。

（1）ALC 下地とアンカー間は、繰り返し載荷の影響により、その耐 力は低下する。

（2）繰り返し載荷後の保持耐力は、固定工法により差異があり、直 接ねじ込み、プラグとの併用、さらにエポキシ樹脂接着剤の事 前注入の順に、而疲労特性は向上寸る。

（3）現行の防水システムについては、ALC 下地の強度に問題がある というよりは、防水シートもしくはシートからアンカーへの力 の伝達させる部分に弱点のある可能性が指摘された。これは、 従来、多数回の疲労のことは検討されていなかったため、盲点 となっていた部分であるが、今後はこの点の検討と、構・工法 の改善が必要と思われる。
なおここでの研究は、すべて材料が全く劣化していない健全な状 態での結果である。実際の使用では材料は劣化する。ウェザリング を前提とした耐久性の面からの研究は今後の課題である。

謝辞

本研究を進めるにあたり、日本建築学会防水工事運営委員会、防 水層 ALC 機械固定工法 WG の委員の協力を得た。また試験装置の設 計、試作には応用セラミックス研究所、石井元氏の協力を得た。心 より謝意を表すものである。

\section{参考文献}

1)市川祐一、バルコ ミハエル、加藤信男、宮内博之、佐々木孝基、田中享二： 機械固定工法による防水層の挙動の風洞実験による観察; 日本建築学会構造系論 文集、第 593 号、pp. 17-23、2005. 7

2) 日本建築学会 : 建築工事模準仕様書・同解缾 JASS 8 防水工事、2000

3)バルトコ ミハエル、宮内博之、田中享二：ALCを下地とする防水層機械固定工 法の耐風性試験方法の開発 ; 日本建筑学会構造系論文集、第 598 号、p7-12、 2005. 12

4) Baskaran, A., Chen, Y., Vilaipornasawai, U. : A New Dynamic Wind Load Cycle to Evaluate Mechanically Attached Flexible Membrane Roofs, Journal of Testing and Evaluation, pp. 249-265, 1999

5) Baskaran, A., Chen, Y. : Wind Load Cycle Development for Evaluating Mechanically attached Single-ply Roofs, Journal of Wind Engineering and Industrial Aerodynamics, pp. 83-96, 1998

6) Baskaran, A., Chen, Y., Lei, W. : Wind Load Resistance of Modified Bituminous Roofing Systems, Construction and Building Materials, pp. 471-480, 1998 7) JIS A 6008 : 合成高分子系ルーフィングシート, 2002

8) 日本建築学会:防水関連の台風被害状況調查結果の報告; 第3回防水シンポジウム 资料集, 2005

[2006年 3 月 6 日原稿受理 2006 年 7 月27日採用決定］ 